\title{
IDENTIFIKASI BAKTERI ESCHERICHIA COLI DAN SALMONELLA SP. PADA MAKANAN JAJANAN BAKSO TUSUK DI KOTA MANADO
}

\author{
${ }^{1}$ Yolanda Arlita \\ ${ }^{2}$ Fredine E. S. Rares \\ ${ }^{2}$ Standy Soeliongan \\ 1 \\ 2 \\ Kandidat Skripsi Fakultas Kedokteran Universitas Sam Ratulangi Manado \\ Bagian Mikrobiologi Fakultas Kedokteran Universitas Sam Ratulangi Manado \\ E-mail: yolandaarlita@yahoo.com
}

\begin{abstract}
Public awareness of food hygiene is very important because consumption of contaminated food can cause foodborne diseases. The most common causative bacteria are Escherichia coli and Salmonella sp. The occurence of bacteria on the food is due to the less attention of the food sellers. In Manado, 'bakso tusuk' is consumed by public, especially students. This study aimed to identify the bacteria $E$. coli and Salmonella sp. in 'bakso tusuk' sold in Manado. This was a descriptive prospective study. Samples were taken randomly from 20 'bakso tusuk' sellers in Manado. Samples were examined bacteriologically to determine their sanitary quality. The results showed that E. coli and Salmonella sp. were found in 17 of 20 samples 'bakso tusuk'. E. coli and Salmonella sp. were isolated from 17(85\%) and 9 (45\%) of 20 samples 'bakso tusuk'. Conclusion: Most of 'bakso tusuk' sold in Manado contained bacteria Escherichia coli (the most) and Salmonella sp..
\end{abstract}

Keywords: bakso tusuk, Escherichia coli, Salmonella sp.

\begin{abstract}
Abstrak: Kesadaran masyarakat mengenai kebersihan makanan perlu mendapat perhatian karena makanan tercemar dapat menyebabkan penyakit bawaan makanan. Bakteri penyebab yang paling umum ialah Escherichia coli dan Salmonella sp. Bakteri dalam makanan dapat merupakan dampak dari penjualan makanan yang tidak memperhatikan kebersihan. Di Manado, makanan jajanan bakso tusuk diminati oleh masyarakat terutama para siswa dan mahasiswa dan dijual secara bebas.. Penelitian ini bertujuan untuk mengidentifikasi bakteri E.coli dan Salmonella sp. dalam makanan jajanan bakso tusuk di Manado. Penelitian ini bersifat deskriptif prospektif. Sampel diambil dari 20 pedagang bakso tusuk di Kota Manado kemudian dilakukan uji pemeriksaan bakteriologik untuk menentukan kualitas sanitasi. Hasil penelitian mendapatkan E. coli dan Salmonella sp. pada 17 dari 20 sampel bakso tusuk. E. coli diisolasi dari 17 (85\%) sampel bakso tusuk sedangkan Salmonella sp. dari 9 (45\%) sampel. Simpulan: Sebagian besar jajanan bakso tusuk di Manado mengandung bakteri, yaitu Escherichia coli (terbanyak) dan Salmonella sp.

Kata kunci: bakso tusuk, Escherichia coli, Salmonella sp.
\end{abstract}


Kesadaran masyarakat mengenai kebersihan makanan merupakan hal yang perlu diperhatikan, karena makanan atau minuman yang mengandung bahan tercemar bila dikonsumsi akan menyebabkan penyakit bawaan makanan atau foodborne illness, yaitu penyakit yang ditularkan melalui makanan. Penyakit bawaan makanan oleh bakteri umumnya akan menimbulkan gejala diare. ${ }^{1}$

Penyakit bawaan makanan oleh bakteri dapat berupa intoksifikasi atau infeksi. Intoksifikasi melalui makanan disebabkan oleh adanya toksin bakteri yang terbentuk didalam makanan pada saat bakteri bermultiplikasi, sedangkan infeksi melalui makanan disebabkan oleh masuknya bakteri ke dalam tubuh melalui makanan yang terkontaminasi dan tubuh memberikan reaksi terhadap bakteri tersebut. Kedua hal ini akan menyebabkan penyakit pada saluran cerna. ${ }^{2}$ Bakteri paling umum yang menyebabkan infeksi melalui makanan adalah Salmonella dan E. coli. ${ }^{3}$

Bakteri dalam makanan dapat diakibatkan oleh penjualan makanan yang tidak memperhatikan kebersihan dan keamanannya, misalnya di Indonesia, khususnya di Kota Manado, penjualan makanan dilakukan secara bebas sehingga dapat ditemukan banyak penjual makanan jajanan yang berjualan di pinggir jalan. Bakso tusuk merupakan salah satu makanan jajanan yang diminati oleh masyarakat terutama para siswa dan mahasiswa. Bakso tusuk merupakan makanan jajanan yang menggunakan daging sebagai salah satu bahannya. Risiko penularan infeksi melalui makanan produk hewan juga berhubungan dengan daging yang terkontaminasi. Daging mentah yang terkontaminasi merupakan salah satu sumber utama penyakit bawaan makanan. ${ }^{4}$

Di seluruh dunia, penyakit bawaan makanan terutama diare, merupakan penyebab utama morbiditas dan mortalitas. ${ }^{5}$ Di Amerika Serikat, penyakit bawaan makanan oleh bakteri telah menyebabkan kesakitan sekitar 6,5 hingga 33 juta kasus dan 9.000 kematian setiap tahunnya. ${ }^{6}$ Infeksi Salmonella adalah infeksi yang paling umum dilaporkan. Pada tahun 2010 terdapat 8.256 kasus infeksi (17,6 penyakit per 100.000 orang) dan memiliki jumlah terbesar dari rawat inap dengan jumlah 2.290 kasus dan kematian 29 kasus. Kejadian infeksi Salmonella pada 2010 tidak berbeda secara signifikan dibandingkan selama 1996-1998 tetapi secara signifikan lebih tinggi dari tahun 2006 - 2008 (peningkatan $10 \%)^{7}$

Di negara Indonesia, diare merupakan masalah kesehatan masyarakat karena morbiditas dan mortalitas-nya yang masih tinggi. Survei morbiditas yang dilakukan oleh Subdit Diare, Departemen Kesehatan dari tahun 2000 s/d 2010 terlihat kecenderungan insidens naik. Pada tahun 2000 penyakit Diare 301/ 1000 penduduk, tahun 2003 naik menjadi 374 /1000 penduduk, tahun 2006 naik menjadi 423 /1000 penduduk dan tahun 2010 menjadi 411/1000 penduduk. ${ }^{8} \quad$ Kasus infeksi Salmonella di Indonesia juga cukup banyak dan mengkhawatirkan. Indonesia dikategorikan sebagai salah satu negara dengan kejadian endemik salmonellosis tertinggi di Asia setelah Cina dan India, dan diikuti Pakistan dan Vietnam. ${ }^{9}$

Di Kota Manado kasus diare dilaporkan pada tahun 2010 berjumlah 1.939 dengan angka kesakitan 4 per 100 penduduk. Gambaran kasus diare tahun 2010 di Kota Manado, kasus tertinggi berada di wilayah kerja Puskesmas Sario dengan jumlah 358 kasus dan yang terendah adalah Puskesmas Minanga dengan jumlah kasus 48 dan semua dapat ditangani. ${ }^{10}$

Berdasarkan UU Makanan No. 7 tahun 1996, keamanan makanan adalah kondisi dan upaya yang diperlukan untuk mencegah makanan dari kemungkinan cemaran biologis, kimia dan benda lain yang dapat mengganggu, merugikan dan 
membahayakan kesehatan manusia. ${ }^{11}$ Analisis mikrobiologi penting dalam menentukan keamanan dan kualitas dari suatu makanan, oleh sebab itu pada penelitian ini dimaksudkan untuk menilai keberadaan bakteri dalam daging dengan fokus sampel penelitian yaitu makanan jajanan bakso tusuk di Kota Manado. Saat ini penulis belum menemukan adanya penelitian mengenai keamanan dan kualitas dari makanan jajanan bakso tusuk di Kota Manado. Berdasarkan uraian latar belakang diatas, penulis tertarik untuk meneliti keamanan dari segi bakteriologis makanan jajanan bakso tusuk di Kota Manado.

\section{METODE PENELITIAN}

Penelitian ini bersifat deskriptif prospektif yaitu untuk mengidentifikasi bakteri Escherichia coli dan Salmonella sp. pada daging bakso. 20 sampel diambil secara acak dari 20 penjual bakso tusuk di Kota Manado. Tiap sampel dibawa dengan wadah steril dan langsung dikirim ke laboratorium untuk dilakukan pemeriksaan. Tiap sampel ditimbang 25 gram kemudian dihancurkan dengan blender steril lalu

Tabel 1. Bakteri yang terisolasi dari sampel yang diperiksa

\begin{tabular}{ccl}
\hline & Jumlah & $\mathbf{\%}$ \\
\hline Escherchia coli & 17 & $85 \%$ \\
Salmonella & 9 & $45 \%$ \\
TAP & 3 & $15 \%$ \\
\hline
\end{tabular}

diencerkan dengan menambahkan $90 \mathrm{ml}$ aquadest kemudian disaring dan ampasnya dibuang. Dengan kawat ose steril diambil bahan secara aseptis sampel yang sudah di encerkan kemudian masukan kedalam media BGLB 2\%, lalu dimasukan ke dalam inkubator suhu $37^{\circ} \mathrm{C}$ selama 24-48 jam. Pembacaan dilakukan setelah 48 jam dengan melihat jumlah tabung BGLB 2\% yang menunjukan positif gas. Bahan dari media BGLB $2 \%$ yang menunjukan positif gas diambil secara aseptis untuk kemudian dilakukan penanaman pada media Mc
Conkey Agar dan SS Agar, kemudian di inkubasikan dengan suhu $37^{0}$ selama 48 jam. Setelah masa inkubasi selesai, diamati jika pada masing-masing media ada pertumbuhan koloni, selanjutnya dari kedua media, diambil koloni secara aseptis untuk dilakukan pemeriksaan identifikasi dengan memakai pewarnaan gram dan untuk mengidentifikasi Salmonella dengan uji biokimia.

\section{HASIL PENELITIAN}

\section{Hasil Penanaman Pada Media dan Pengecatan Gram}

Dari 20 sampel yang di dapat dilakukan penanaman pada media Brilliant Green Lactose Bile Broth (BGLB) untuk melihat ada atau tidaknya pertumbuhan bakteri gram negatif yang memfermentasikan laktosa dengan melihat terbentuk atau tidaknya gas, dan didapati hasil sebanyak 17 sampel (85\%) yang membentuk gas.

Dari 17 sampel yang membentuk gas (bakteri coliform) kemudian dilakukan penanaman pada media SalmonellaShigella Agar (SSA) dan McConkey Agar (MCA) dan setelahnya dilakukan pengecatan gram dan didapati jumlah sampel yang mengandung bakteri Escherichia coli sebanyak 17(85\%) dari 20 sampel dan yang mengandung bakteri Salmonella sebanyak 9(45\%) dari 20 sampel.

\section{BAHASAN}

Telah dilakukan penelitian terhadap bakso tusuk yang dijual di beberapa tempat di Manado pada periode Desember 2013Januari 2014 yang dilaksanakan di Laboratorium Mikrobiologi FK Unsrat. Beberapa uji yang telah dilakukan pada penelitian antara lain uji Escherchia coli dan Salmonella sp. Uji Eschericia coli digunakan untuk menentukan keberadaan bakteri Escherchia coli pada makanan atau minuman. Uji ini menggunakan media salah 
satunya Brilliant Green Lactose Broth (BGLB) 2\% yang merupakan media yang digunakan untuk penanaman sampel pertama kali. Media ini mengandung Laktosa yang mendukung pertumbuhan bakteri gram negatif dan juga mengandung Bile Salt atau garam empedu sebagai penghambat pertumbuhan bakteri gram postif. Itu sebabnya pada penelitian ini tidak ditemukan adanya bakteri gram positif pada 20 sampel yang diteliti. Escherchia coli merupakan bakteri gram negatif yang memfermentasikan laktosa yang berada didalam BGLB dalam suhu kamar $37-38^{\circ} \mathrm{C}$ dalam waktu 24-48 jam sehingga terbentuk gas. Dalam uji ini ditemukan sampel yang mengandung Escherchia coli sebanyak 17 sampel dari 17 tabung yang membentuk gas. Escherchia coli, atau biasa disingkat $E$. coli, adalah salah satu jenis spesies utama bakteri gram negatif. Bakteri ini merupakan salah satu dari family Enterobacteriaceae yang merupakan flora normal di dalam usus besar manusia. Keracunan makanan yang disebabkan oleh $E$. coli enteropatogenik biasanya disebabkan oleh konsumsi air atau makanan yang terkontaminasi oleh E. coli dalam jumlah yang banyak. ${ }^{12}$

Uji Salmonella sp. digunakan untuk menentukan keberadaan bakteri Salmonella pada makanan. Pada uji ini ditemukan sampel yang mengandung bakteri Salmonella sebanyak 9 dari 20 sampel. Salmonella merupakan bakteri gram-negatif berbentuk batang yang menyebabkan typhus, paratyphus, dan penyakit foodborne. Bakteri ini bukan indikator sanitasi, melainkan bakteri indikator keamanan makanan. Salmonella memiliki banyak serotype yang semuanya diketahui bersifat patogen, sehingga adanya bakteri ini dalam makanan dianggap membahayakan kesehatan. Salmonella tidak meninggalkan bau maupun rasa apapun pada makanan, kecuali jika bahan makanan (daging) mengandung Salmonella dalam jumlah besar, maka akan terjadi perubahan warna dan bau (merah muda pucat sampai kehijauan, berbau busuk). ${ }^{13}$ Pada penelitian ini, sampel yang diambil tidak ditemukan adanya perubahan warna dan bau pada daging, sehingga kemungkinan Salmonella yang terkandung dalam sampel dalam jumlah yang sedikit, namun hal ini belum dapat dipastikan karena pada penelitian ini tidak dilakukan pemeriksaan angka kuman karena keterbatasan waktu. Perkiraan dosis infeksius Salmonella yaitu apabila terdapat lebih dari 100 sel bakteri. Apabila kurang dari itu, bakteri akan mati oleh asam lambung dan tidak akan menimbulkan penyakit. $^{14}$ Salmonella bisa terdapat di udara, air, tanah, sisa kotoran manusia maupun hewan atau makanan hewan. Yang sangat sering terjadi adalah keracunan Salmonella dari makanan seperti daging mentah (terutama daging cincang), daging unggas, ikan, telur, makanan yang mengadung telur mentah. ${ }^{12}$

Dari hasil tersebut diatas didapati sekitar 17(85\%) dari 20 penjual bakso tusuk yang diambil secara acak di Kota Manado mengandung bakteri gram negatif dengan perbandingan E.coli lebih banyak dari Salmonella. Mengacu pada penelitian lain yang dilakukan oleh Al-Mutairi mengenai Enterobactertiaceae dalam makanan produk daging dengan jumlah 75 sampel yang diambil dari berbagai supermarket di Mesir, menunjukan bahwa 33 dari 75 sampel (44\%) makanan produk daging ini mengandung bakteri Enterobacteriaceae, dengan persentase hasil sampel yang mengandung E.coli sebanyak 20\% dan Salmonella 4\%, dan sisanya jenis Enterobacteriaceae yang lain, dengan E.coli yang memiliki persentase terbesar. ${ }^{6}$

Enterobacteriaceae dapat terkandung dalam makanan sebagai mikroflora yang alami atau juga dapat sebagai hasil kontaminasi setelah makanan tersebut diproses. Escherichia dan Salmonella dapat memasuki rantai makanan melalui kontaminasi feses dan ini mungkin 
terkait dengan makanan tertentu seperti daging dan unggas. ${ }^{13}$ Namun karena keterbatasan waktu, dalam penelitian ini tidak dilakukan evaluasi mengenai kebersihan pengolahan makanan.

Bakso tusuk dalam pembuatannya dilakukan pemanasan dalam hal ini direbus, dan dalam penyajiannya juga dalam suhu hangat. Namun, dalam penelitian ini tidak dilakukan evaluasi mendalam mengenai cara pembuatan dan penyajian sehingga tidak dapat dipastikan suhu yang digunakan saat pembuatan dan penyajian. Salmonella dan EHEC adalah bakteri mesofilik dengan suhu pertumbuhan berkisar antara 15 dan $40^{\circ} \mathrm{C}$. Pendinginan pada suhu pendingin normal $\quad 0-8^{\circ} \mathrm{C}$ dapat menghambat pertumbuhan, tetapi tidak menginaktivasi, oleh karena itu bakteri-bakteri ini hanya berkembang biak di produk yang mudah rusak ketika disimpan di suhu yang tidak sesuai. Pertumbuhan optimum pada suhu $37^{\circ} \mathrm{C}$ khas untuk Enterobacteriaceae asal feses. Enterobacteriaceae tahan panas, termasuk strain $E$. coli mampu bertumbuh hingga $44^{\circ} \mathrm{C}$ dan memiliki suhu minimum untuk pertumbuhan lebih dari $7-8^{\circ} \mathrm{C} .^{13}$

\section{SIMPULAN}

Dari hasil penelitian dapat disimpulkan bahwa sebagian besar jajanan bakso tusuk di Manado mengandung bakteri, yaitu Escherichia coli (terbanyak) dan Salmonella sp.

\section{DAFTAR PUSTAKA}

1. NSW Government Health Indonesian. Penyakit Bawaan Makanan. Multicultural Health Communication. [cited 2013 September 11]. Available from:

http://www.mhcs.health.nsw.gov.au/pu blicationsandresources/pdf/publicationpdfs/diseases-and-conditions/7120/doh7120-ind.pdf
2. Badan POM RI. Pengujian Mikrobiologi Makanan. InfoPOM Pengawas Obat dan Makanan Republik Indoneisa Vol. 9, No. 2. Maret 2008. [cited 2013 September 12]. Available from:

http://perpustakaan.pom.go.id/Koleksi Lainnya/Buletin\%20Info\%20POM/020 8.pdf

3. Sentra Informasi Keracunan Nasional, Badan POM RI. Keracunan Makanan Akibat Bakteri Patogen. 2011. Available from: http://ik.pom.go.id/v2012/wpcontent/uploads/2011/11/KeracunanPangan-Akibat-Bakteri-Patogen3.pdf

4. WHO. Penyakit Bawaan Makanan: Fokus Pendidikan Kesehatan. Palupi Widyastuti S, editor. Jakarta: Penerbit Buku Kedokteran EGC; 2006. h 2-3

5. WHO. Foodborne Disease Surveillance. Available from: http://www.who.int/foodborne_disease/ en/index.html

6. Al-Mutairi MF. The Incidence of Enterobacteriaceae Causing Food Poisoning in Some Meat Products. Advance Journal of Food Science and Technology 3(2): 116-121. 2011.

7. CDC. Vital Signs: Incidence and Trends of Infection with Pathogens Transmitted Commonly Through Food. Foodborne Disease Active Surveillance Network, 10 U.S. Sites, 1996-2010. 2011. Available from: http://www.cdc.gov/mmwr/preview/m mwrhtml/mm6022a5.htm\#Tab1

8. Kementrian Kesehatan RI. Buletin Jendela Data dan Informasi Kesehatan. Situasi Diare di Indonesia. 2011. Available from: http://www.depkes.go.id/downloads/Bu letin\%20Diare_Final(1).pdf

9. Ochiai,R. A Study of Typhoid Fever in Five Asian Countries:Disease Burden and Implications for Controls. Bulletin WHO 86(4). 2008 
10. Profil Dinas Kesehatan Kota Manado. 2010. h 14,76-7

11. Undang-Undang No. 7 Tahun 1996 Tentang Makanan. [cited 2013 September 12]. Available from: http://bk.menlh.go.id/files/UU-796.pdf

12. Arifah IN. Tugas Akhir Magang di Balai Besar Pengawas Obat dan Makanan Yogyakarta "Analisis Mikrobiologi Dalam Makanan”. Universitas Sebelas Maret Surakarta. 2010.

13. Baylis C, Uyttendaele M, Joosten H, Davies A. The Enterobacteriaceae and
Their Significance To The Food Industry. Brussels: International Life Sciences Institute, ILSI Microbiological Issues Task Force; 2011. Report No.: ISBN.

14. The U.S. Food and Drug Administration Center for Food Safety and Applied Nutrition. Foodborne Illness-Causing Organisms in the U.S. [cited 2013 September 12]. Available from:

http://www.fda.gov/downloads/food/re sourcesforyou/consumers/ucm187482. pdf 